\title{
Nilai Estetika Kacaping Sebagai Konsep Dasar Pendidikan Karakter Pada Pendidikan Formal Masyarakat Bugis di Kabupaten Sidrap
}

\author{
Andi Ihsan \\ Program Studi Pendidikan Seni Drama, Tari, dan Musik, Fakultas Seni dan Desain, \\ Universitas Negeri Makassar \\ andiihsanleo@yahoo.com
}

\begin{abstract}
Kacaping merupakan salah-satu produk budaya masyarakat bugis khususnya di kabupaten Sidrap, Sulawesi-Selatan. Secara estetika, kacaping memiliki nilai-nilai baik ekstrinsik maupun intrinsik, yang tentunya dapat menjadi nilai-nilai lokal sebagai peletak dasar pendidikan karakter bagi generasi penerus. Di dalam pendidikan formal dikenal domain yang terintegrasi ke dalam satu kesatuan pembelajaran yang menjadi sasaran atau tujuan dari pendidikan tersebut yakni kognitif, afektif dan psikomotorik. Aspek-aspek tersebut idealnya bersumber dari nilai-nilai lokal kedaerahan sehingga pendidikan karakter yang diharapkan benar-benar dapat terwujud sesuai sasaran yang diinginkan. Nilai-nilai kedaerahan sebagai dasar pembentukan karakter generasi terdapat dalam kacaping. Adapun rumusan masalah dalam penelitian ini adalah (1) bagaimana nilai ekstrinsik kacaping sebagai konsep dasar kurikulum pendidikan formal berbasis pendidikan karakter pada masyarakat bugis di kabupaten sidrap, (2) bagaimana konsep pendidikan formal melalui nilai estetika kacaping pada masyarakat bugis di kabupaten Sidrap. Jenis penelitian ini adalah penelitian kualitatif melalui pendekatan etnomusikologi didukung dengan ilmu-ilmu lannya yang relevan. Hasil penelitian menunjukkan bahwa kacaping bugis di kabupaten Sidrap memiliki estetika yakni nilai-nilai baik nilai ekstrinsik maupun nilai intrinsik yang melekat pada kacaping, maupun pada penyajian kacaping tersebut di masyarakat. Dengan mengangkat nilai-nilai estetika kacaping ke dalam proses pendidikan formal berbasis pendidikan karakter maka tujuan pendidikan karakter yang diharapkan benar-benar dapat terwujud.
\end{abstract}

Kata kunci: kacaping, nilai estetika, pendidikan karakter

\section{The Aesthetic Value of Kacaping as a Basic Concept of Curriculum Formal Education Based on Character Education on the Bugis Community in Sidrap District}

Kacaping is one of the Bugis community cultural products, especially in Sidrap, South Sulawesi. Aesthetically, kacaping has both extrinsic and intrinsic values, which of course can become local values as the foundation for character education for future generations. In formal education, it is known that domains are integrated into one unit of learning which is the target or goal of the education, namely cognitive, affective and psychomotor. These aspects ideally originate from local regional values so that the expected character education can truly be realized according to the desired goals. Regional values as the basis for generation of character generation are found in peeling. The formulation of the problem in this study are (1) how extrinsic kacaping value as a basic concept of formal education curriculum based on character education on the Bugis community in Sidrap district, (2) how the concept of formal education through aesthetic value to the Bugis community in Sidrap district. This type of research is qualitative research through ethnomusicology approach supported by other relevant sciences. The results of the study show that kacaping bugis in Sidrap district has aesthetics, namely the values of both extrinsic values and intrinsic values that are inherent in the mirror, as well as the presentation of the nuts in the community. By elevating the aesthetic values of glasses to the process of formal education based on character education, the expected character education goals can truly be realized.

Keywords: kacaping, aesthetic value, character education

Proses Review : 1 - 18 April 2019, Dinyatakan Lolos: 22 April 2019 


\section{PENDAHULUAN}

Pendidikan adalah suatu hak dan kewajiban yang harus dilaksanakan setiap manusia. Dari pendidikan seseorang akan belajar menjadi seorang yang berkarakter dan mempunyai ilmu pendidikan dan sosial yang tinggi. Pendidikan yang baik akan melahirkan generasi penerus bangsa yang cerdas dan kompeten dalam bidangnya. Sehingga kondisi bangsa akan terus mengalami perbaikan dengan adanya para penerus generasi bangsa yang mumpuni dalam berbagai ilmu.

Pendidikan karakter merupakan suatu sistem penanaman nilai-nilai karakter yang meliputi komponen pengetahuan, kesadaran atau kemauan, dan tindakan untuk melaksanakan nilai-nilai tersebut. Pendidikan karakter dapat dimaknai sebagai "the deliberate use of all dimensions of school life to foster optimal character development". pendidikan karakter memiliki esensi dan makna yang sama dengan pendidikan moral dan pendidikan akhlak yang bertujuan untuk membentuk pribadi anak, supaya menjadi manusia yang baik, warga masyarakat, dan warga negara yang baik.

Pendidikan karakter merupakan upaya-upaya yang dirancang dan dilaksanakan secara sistematis untuk membantu peserta didik memahami nilai-nilai perilaku manusia yang berhubungan dengan Tuhan Yang Maha Esa, diri sendiri, sesama manusia, lingkungan, dan kebangsaan yang terwujud dalam pikiran, sikap, perasaan, perkataan, dan perbuatan berdasarkan norma-norma agama, hukum, tata krama, budaya, dan adat istiadat. Ada 18 nilai-nilai dalam pendidikan karakter menurut Diknas (Pusat Kurikulum Departemen Pendidikan Nasional, 2010), yaitu: (1) Religius. Sikap dan perilaku yang patuh dalam melaksanakan ajaran agama yang dianutnya, toleran terhadap pelaksanaan ibadah agama lain, dan hidup rukun dengan pemeluk agama lain. (2). Jujur. Perilaku yang didasarkan pada upaya menjadikan dirinya sebagai orang yang selalu dapat dipercaya dalam perkataan, tindakan, dan pekerjaan. (3). Toleransi. Sikap dan tindakan yang menghargai perbedaan agama, suku, etnis, dan tindakan orang lain yang berbeda dirinya (4). Disiplin. Tindakan yang menunjukkan perilaku tertib dan patuh pada berbagai ketentuan peraturan. (5). Kerja keras. Tindakan yang menunjukkan perilaku tertib dan patuh pada berbagai ketentuan peraturan. (6).Kreatif. Berpikir dan melakukan sesuatu untuk menghasilkan cara atau hasil baru dari sesuatu yang telah dimiliki. (7). Mandiri. Sikap dan perilaku yang tidak mudah tergantung pada orang lain dalam menyelesaikan tugas-tugas. (8). Demokratis. Cara berfikir, bersikap, dan bertindak yang menilai sama hak dan kewajiban dirinya dan orang lain. (9). Rasa Ingin Tahu. Sikap dan tindakan yang selalu berupaya untuk mengetahui lebih mendalam dan meluas dari sesuatu yang dipelajarinya, dilihat, dan didengar. (10). Semangat Kebangsaan. (11). Cinta Tanah Air. Cara berpikir, bertindak, dan berwawasan yang menempatkan kepentingan bangsa dan negara di atas kepentingan diri dan kelompoknya. (12). Menghargai Prestasi. Sikap dan tindakan yang mendorong dirinya untuk menghasilkan sesuatu yang berguna bagi masyarakat, dan mengakui, serta menghormati keberhasilan orang lain. (13) Bersahabat/Komunikatif. Sikap dan tindakan yang mendorong dirinya untuk menghasilkan sesuatu yang berguna bagi masyarakat, dan mengakui, serta menghormati keberhasilan orang lain. (14). Cinta Damai. Sikap dan tindakan yang mendorong dirinya untuk menghasilkan sesuatu yang berguna bagi masyarakat, dan mengakui, serta menghormati keberhasilan orang lain. (15). Gemar Membaca. Kebiasaan menyediakan waktu untuk membaca berbagai bacaan yang memberikan kebajikan bagi dirinya. (16). Peduli Lingkungan. Sikap dan tindakan yang selalu berupaya mencegah kerusakan pada lingkungan alam di sekitarnya, dan mengembangkan upaya-upaya untuk memperbaiki kerusakan alam yang sudah terjadi. (17). Peduli Sosial. Sikap dan tindakan yang selalu ingin memberi bantuan pada orang lain dan masyarakat yang membutuhkan. (18). Tanggung Jawab. Sikap dan perilaku seseorang untuk melaksanakan tugas dan kewajibannya, yang seharusnya dia lakukan, terhadap diri sendiri, masyarakat, lingkungan (alam, sosial dan budaya), negara dan Tuhan Yang Maha Esa.

Kemajuan teknologi dan perubahan yang terjadi memberikan kesadaran baru bahwa Indonesia tidak lagi berdiri sendiri. Indonesia berada di tengah-tengah dunia yang baru, dunia terbuka sehingga orang bebas membandingkan kehidupan dengan negara lain. Oleh karena itu, kita seharusnya dapat meningkatkan sumber daya manusia Indonesia yang tidak kalah bersaing dengan sumber daya manusia di negara-negara lain.

Penyebab rendahnya mutu pendidikan di Indonesia antara lain adalah masalah efektivitas, efisiensi dan standarisasi pengajaran. Hal tersebut masih menjadi masalah pendidikan di Indonesia pada umumnya. Selain kurang kreatifnya para pendidik dalam membimbing siswa, kurikulum yang sentralistik membuat potret pendidikan semakin buram. Kurikulum hanya didasarkan pada pengetahuan pemerintah tanpa memperhatikan kebutuhan masyarakat. Pendidikan tidak mampu menghasilkan lulusan yang kreatif. Kurikulum dibuat secara terpusat dan tidak memperhatikan kondisi di masyarakat bawah atau di daerah sampai daerah terpencil.

Kebudayaan adalah keseluruhan yang kompleks, yang di dalamnya terkandung ilmu pengetahuan, kepercayaan, kesenian, moral, hukum, adat istiadat dan kemampuan yang lain, serta kebiasaan yang didapat oleh manusia sebagai anggota masyarakat (Taylor 1958:1). Kesenian sebagai salah-satu wujud kebudayaan telah hadir pada masyarakat Bugis jauh sebelum terbentuknya Negara Indonesia bahkan sebelum masuknya agama islam. Kesenian tersebut hadir sesuai dengan kebutuhan-kebutuhan yang ada di dalam masyarakat baik itu sebagai kebutuhan ritual, maupun kebutuhan-kebutuhan yang sifatnya profan, keduanya saling terkait satu dengan lainnya. 
Salah satu benda seni sebagai produk budaya masyarakat Bugis yaitu kacaping. Kacaping adalah alat musik tradisional petik yang bentuknya menyerupai perahu dan memiliki dua senar dan sering dimainkan oleh masyarakat Bugis di berbagai kegiatan atau acara-acara hiburan. Alat ini merupakan salah-satu alat musik yang sangat popular yang ada di masyarakat Bugis.

Sampai saat ini kacaping juga telah masuk pada pendidikan formal sebagai media pembelajaran musik tradisional untuk mendukung kurikulum 2013 yang di dalamnya terdapat pendidikan karakter melalui budaya lokal. Hal ini merupakan peluang bagaimana kacaping sebagai produk budaya masyarakat Sidrap dapat mendukung pembelajaran dalam membentuk karakter generasi sesuai nilai-nilai budaya lokal masyarakat bugis di kabupaten Sidrap.

The Liang Gie (1976:38), membagi nilai menjadi dua yaitu nilai ekstrinsik dan nilai intrisik. Nilai ekstrinsik merupakan sifat baik atau bernilai dari sesuatu benda sebagai suatu alat atau sarana untuk sesuatu hal lainnya sering disebut juga dengan instrumental yakni nilai yang bersifat alat atau membantu. Nilai intrisik yaitu sifat baik atau bernilai dalam dirinya atau sebagai suatu tujuan ataupun demi kepentingan sendiri dari benda yang bersangkutan. Nilai intrisik itu adalah kebenaran, kebaikan dan keindahan. Pada hakikatnya seni tradisi merupakan sebuah ekspresi kultural yang sebagai subjek kolektif yang terikat oleh karakteristik ranah budaya masing-masing sehingga identitas dan nilai kearifan lokalnya turut terbawa serta (dalam Ganap, 2012, Desyandri, 2017).

Menurut teori nilai dari Kluckhohn (1961 :219) bahwa "Hal-hal yang paling tinggi nilainya dalam tiap kebudayaan hidup manusia minimal ada 5 hal, yaitu (a) human nature atau makna hidup manusia; (b) man nature atau makna dari hubungan manusia dengan alam sekitarnya; (c) time, yaitu persepsi manusia mengenai waktu; (d) activity, yaitu masalah makna dari pekerjaan, karya, dan amal dari perbuatan manusia; (e) relationa, yaitu hubungan manusia dengan sesama manusia.

Beberapa nilai yang mengawali pembentukan kebudayaan Bugis diciptakan karena dimuliakan oleh leluhur mereka sebagai peletak dasar masyarakat dan kebudayaan Bugis, kemudian dialihkan turun-temurun dari satu generasi ke genarasi berikutnya. Dalam usaha mewariskannya, mereka menasehatkan atau memesankan. Nasehat dan petaruh itu termaktub di dalam Lontara'-lontara' yang disebut pappanngaja dan paseng.

Pappanngaja' adalah sesuatu yang dinasehatkan. Kadangkadang merupakan ungkapan berupa kata-kata hikmah, dan adakalanya melalui suatu cerita yang di dalamnya ditaburkan beberapa buah ibarat. Semua sifat dan tingkah laku yang dimajukan, memberikan kesan bahwa ia terpuji dan mulia. Sedangkan jika ia dalam bentuk cerita, maka ceritanya adalah tentang hal-hal yang baik, yang benar dan semacamnya, selalu unggul dan menang. Pappanngaja itu dituntut oleh orang tua kepada anak atau cucu, oleh guru kepada muridnya, oleh kakak kepada adiknya, oleh suami kepada istrinya. Tetapi tidak jarang pula, raja sendiri yang meminta dinasehati, sehingga pappanngaja' sebenarnya berfungsi memberi ingat (Rahman Rahim, 66: 2011).

Paseng berarti wasiat yang dipertaruhkan. Ia menekankan tentang keharusan dan pantangan. Orang yang memelihara paseng akan selalu terpandang di masyarakatnya. Sebaliknya mereka yang tak mengindahkannya akan menanggung sanksi sosial yang amat berat. Namanya tercemar dan kedudukan sosial menjadi rendah sehingga sukar sekali buat meraih kembali nama baiknya (Mattulada, 1975: 18).

Enam nilai-nilai utama kebudayaan Bugis dapat diuraikan sebagai berikut: (1) Lempu' (Jujur). Lempu dalam bahasa Indonesia artinya jujur, sama dengan lurus sebagai lawan dari bengkok. Dalam berbagai konteks kata ini berarti ikhlas, benar, baik atau adil. Sehingga lawan katanya adalah culas, curang, dusta, khianat, seleweng, buruk, tipu, aniaya, dan semacamnya. Arti ini dapat dipahami ketika ditemukan kata lempu' dalam ungkapan-ungkapan Bugis atau Lontara. (2) Ammaccang (kepandaian, Intelektual). Dalam bahasa Indonesia berarti kepandaian atau kepintaran dapat dipahami baik dala arti positif maupun negatif. Padahal acca bukan pandai atau pintar tetap cendikia atau intelek (cendikia dari sangsekerta, kearifan dari bahasa Arab). Lontara juga menggunakan kata nawa-nawa yang berarti sama dengan acca. Jadi orang mempunyai nilai acca atau nawa-nawa oleh Lontara disebut Toacca, Tokenawanawa atau Pannawanawa, yang dapat diterjemahkan menjadi cendikiawan, intelektual, ahli pikir atau ahli hikmah arif. (3Asitinajang (Kepatutan, Proper). Dalam bahasa Indonesia artinya kepatutan, kepantasan, kelayakan. Kata ini berasal dari tinaja yang berarti cocok, sesuai, pantas atau patut. Lontara mengatakan "Duduki kedudukanmu, tempati tempatmu. Ade' Wari (adat perbedaan) pada hakekatnya mengatur agar segala sesuatu berada pada tempatnya. Mengambil sesuatu dari tempatnya dan meletakkan sesuatu pada tempatnya termasuk perbuatan mappasitinaja. Nilai kepatutan ini erat hubungannya dengan nilai kemampuan (makamaka) jasmaniah dan rohaniah. Penyerahan atau penerimaan sesuatu, apakah itu amanat atau tugas, haruslah didasarkan atas kepatutan dan kemampuan. Makamaka lebih banyak menekankan penampilan bagi pemangku tanggung jawab. (4) Getteng (Keteguhan, Firm). Getteng dalam bahasa Indonesia artinya teguh, kata inipun berarti tetap, asas atau setia pada keyakinan, atau kuat dan tangguh dalam pendirian, erat memegang sesuatu. Sama halnya dengan nilai kejujuran, nilai kecendikiaan dan nilai kepatutan, nilai keteguhan ini terikat pada makna yang positif. (5) Reso (Usaha, Acceptable). Dalam bahasa Indonesia artinya usaha merupakan nilai kunci bagi pelaksanaan nilai-nilai kejujuran, kecen- 
dikiaan, kepatutan dan keteguhan. Barulah nilai-nilai ini berperanan secara bertepat guna dan berdaya guna apabila didukung oleh nilai usaha. Dengan sendirinya nilai usaha inipun tegak di atas landasan nilai tersebut. (6) Siri' (Harga Diri, Amour Propre, Exalted). Siri' dalam bahasa Indonesia artinya malu yang merupakan adat kebiasaan yang melembaga dan masih besar pengaruhnya dalam budaya kehidupan masyarakat Sulawesi Selatan. Masalah siri' selalu menarik perhatian mereka yang hendak mengenal manusia dari kebudayaan bugis.

Jika dikaitkan dengan pendidikan karakter, pembelajaran ini belum memenuhi aspek pendukung bagaimana kacaping dapat memberikan dampak terhadap pembentukan karakter tersebut. Padahal jika kita melihat dari aspek estetika, di dalam kacaping memiliki nilai-nilai estetika khususnya terkait dengan nilai-nilai kebudayaan bugis yang jika diformulasikan dengan baik akan menghasilkan konsep pendidikan formal khususnya ranah afektif yang tentunya akan bermuara pada pembentukan karakter siswa secara maksimal.

Penelitian ini bertujuan untuk menemukan konsep dasar pendidikan karakter pada lingkungan pendidikan formal dengan mengidentifikasi nilai estetika dari kacaping agar dapat menjadi sebuah konsep pembelajaran untuk membangun generasi yang benar-benar memiliki karakter melalui nilai-nilai kebudayaan masyarakat bugis yang kuat pada masyarakat bugis khususnya di kabupaten Sidrap Sulawesi Selatan.

\section{METODE PENELITIAN}

Penelitian ini menggunakan pendekatan interdisiplin ilmu mengingat bahwa penelitian yang dilakukan bersifat holistik yang menekankan pentingnya keseluruhan dan saling keterkaitan dengan bagian-bagiannya. Hal ini disebabkan karena dalam meneliti sebuah fenomena masyarakat terkait dengan keseniannya, tentunya beberapa pendekatan teori akan saling membutuhkan antara yang satu dengan lainnya.

Penelitian ini adalah penelitian kualitatif, dimana sebuah penelitian kualitatif adalah sebuah penelitian yang mengkaji secara detail dan mendalam tentang sebuah persoalan penelitian. Penelitian kualitatif dilakukan melalui studi etnomusikologi karena sifat musikal dari kacaping tersebut sebagai sebuah seni tradisional khususnya etnis bugis, dimana secara konten musikal akan dilihat seperti apa unsur-unsur musikal yang terdapat dalam kacaping tersebut tentunya terkait dengan tradisi masyarakat setempat. Etnomusikologi merupakan sebuah pendekatan dimana musik tidak hanya dipahami dari aspek aural (pendengaran) saja, tetapi juga meliputi pengkajian sosial, kultural, psikologi, dan estetik (Merriam, 1999:74).
Di dalam penelitian sumber data dibagi ke dalam dua jenis yakni sumber data primer dan sumber data sekunder. Menurut Sugiyono (2006:308), sumber data primer adalah adalah sumber data yang langsung memberikan data kepada pengumpul data, sedangkan sumber data sekunder adalah sumber data yang tidak langsung memberikan data kepada pemgumpul data. Sumber data primer dalam penelitian ini terdiri atas hasil pengamatan langsung di lapangan dan nara sumber kunci yaitu beberapa pembuat dan pemain kacaping di beberapa daerah yang menjadi sampel penelitian ini. Selain itu ada beberapa nara sumber lainnya yang dianggap mengetahui persoalan yang menjadi kajian penelitian ini, tokoh-tokoh seni dan budayawan, pejabat pemerintah yang terkait dengan kebijakan kesenian tradisional, peneliti seni tradisional, guru seni, dan masyarakat sebagai penikmat kesenian tradisional pakkacaping. Data sekunder merupakan data pendukung dari data-data primer, sehingga dalam penelitian ini data pendukung tersebut meliputi dokumen-dokumen yang relevan, kaset-kaset dalam penyajian kacaping, serta beberapa audio maupun video yang berkaitan dengan penelitian ini.

Teknik pengumpulan data dilakukan dalam beberapa cara yaitu (1) Wawancara, teknik wawancara dalam penelitian ini dilakukan dalam dua jenis, pertama, wawancara yang dilakukan secara mendalam dimana pada wawancara mendalam ini, peneliti mengeksplorasi sejumlah topik umum untuk membantu memahami perspektif partisipan, tetapi sebaliknya tetap mempertimbangkan bagaimana partisipan merangkai dan menyusun jawaban (Rohidi, 2011: 208). Wawancara dilakukan melalui beberapa narasumber yang sangat terkait dengan penelitian yang dilakukan, mulai dari beberapa pembuat kecaping yaitu Damis Kattang (63), Karlin Kati (56), Nurdin Amma (64). Wawancara dengan budayawan yaitu Musafir Hasan Pulu (47), Sulang (60). Wawancara dengan Pakacaping sendiri yaitu Lakarodding (65) serta pengawas dan pendidik yaitu Bambang Kaston (56), Thamrin (31), dan Herman Langka (31). (2) Teknik Observasi. Observasi mengungkapkan gambaran sistematis mengenai peristiwa, tingkah laku, benda atau karya yang dihasilkan dan peralatan yang digunakan. Metode observasi adalah metode yang digunakan untuk mengamati sesuatu, seseorang, suatu lingkungan, atau situasi secara tajam terinci, dan mencatatnya secara akurat dalam beberapa cara (Rohidi, 2011: 181). Observasi yang dilakukan secara terlibat langsung dengan beberapa peristiwa kebudayaan, serta pengguna kecaping di masyarakat Bugis kabupaten Sidrap, dan pembelajaran kecapi di sekolah maupun di sanggar

(3) Teknik Perekaman. Teknik perekaman dilakukan sebagai pendukung dan membantu terutama pada saat observasi. Ada tiga kategori perekaman yang akan dilaksanakan dalam penelitian ini, antara lain: Fotografi. Video. Audio. Alat perekaman fotografi dan video yang digunakan ada- 


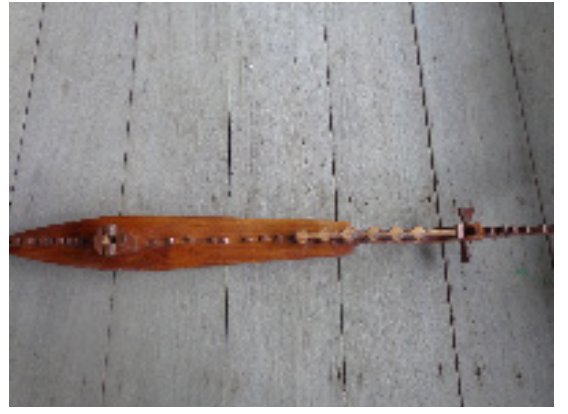

Gambar 1. Kacaping 5 Tuts

(Sumber: Dokumentasi Salahuddin Hasan)

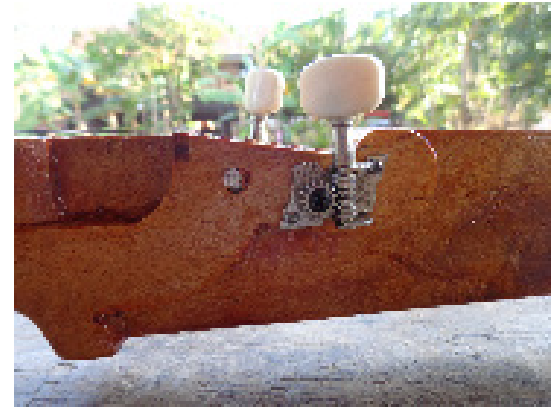

Gambar 2. Lanjong (bagian kepala) (Sumber: Dokumentasi Andi Ihsan) lah kamera SONY dan handphone merk VIVO.

(4) Dokumen. Menurut Moleong (2006:217), dokumen biasanya dibagi atas dokumen pribadi dan dokumen resmi. Peneliti mengumpulkan data tentang kacaping Bugis melalui penelusuran dokumen-dokumen relevan yang dimiliki oleh individu seperti peneliti seni, apresiator seni, praktisi seni, tokoh seni dan lain-lain, atau dimiliki oleh instansi atau organisasi seperti paguyuban seni, dapur rekaman, dan lain-lain.

\section{ANALISIS DAN INTERPRETASI DATA}

\section{Bentuk kecaping di kabupaten Sidrap}

Secara intrinsik, estetika kacaping memiliki bentuk menyerupai perahu, dimana bagian depan dan bagian belakang yang lebih tinggi akan mempermudah posisi pemasangan senar yang dibentangan dari ujung kepala sampai pada ujung ekor kacaping. Bentuknya yang memanjang serta didukung dengan bagian-bagian mulai dari doccili (penyetem senar) di bagian kepala, Isi (Tuts) di bagian tengah, dan Posi' (gagang pemegang senar) yang berada diekor kacaping juga akan memudahkan pemain untuk memegang dan memainkan kacaping sehingga dalam penampilan seorang pakkacaping sering dimainkan dengan santai dan terkadang dimainkan dengan lebih atraktif. Terdapat enam tuts yang dibuat berbentuk bulatan menyesuaikan posisi senar sebagai ruang untuk memainkan nada-nada pada kacaping. Ukurannya yang kecil juga secara ergonomic membuat nyaman bagi pemain untuk melakukan gerakan yang secara teknis bisa dimainkan oleh pakkacaping.

Secara ekstrinsik, estetika dari bentuk kacaping bugis yang menyerupai perahu merupakan cermin dari masyarakat bugis Sidrap yang sejak dahulu menjadikan perahu sebagai sumber kehidupan mereka. Awal mula bentuk kecapi di Sulawesi Selatan secara umum berbentuk perahu sesuai dengan beberapa literatur yang telah disebutkan. Bentuk tersebut tentunya mengacu pada kondisi geografis wilayah Sulawesi Selatan yang hampir seluruhnya memiliki wilayah pesisir, sehingga kecapi selalu diidentikkan dengan masyarakat pesisir dengan alat transportasinya yaitu perahu.
Menurut Salahuddin Hasan bahwa "Pada awal mulanya kecapi yang dibuat oleh sang pelaut adalah dayung perahu yang diberi tali (senar). Kemudian pada perkembangan selanjutnya, kecapi yang dibuat dari dayung diubah bentuknya menjadi kecapi bentuk lepa-lepa (sampan) dengan istilah Kanjilo (yaitu mengikuti bentuk ikan gabus), akhirnya berkembang sampai pada bentuknya yang sekarang menyerupai perahu pinisi. Dengan menggunakan peralatan alat musik yang masih sangat sederhana, para pelaut memetik tali kecapinya tanpa suara atau lagu, yang dikenal dengan Getti Lampana artinya lagu tanpa syair. Mereka memetik kecapi sesuai hati nuraninya sendiri atau inspirasi yang muncul saat mereka kesepian. Hal ini tidak dapat dipungkiri oleh karena kecapi yang pada awal mulanya disebut kanjilo tidak memiliki tuts dalam bahasa bugis dinamakan ISI, begitu pula suara yang terbawa oleh angin". (Salahuddin Hasan, 12-13: 1994).

Dari data tersebut jelas terlihat bahwa mindset tentang perahu sudah sangat melekat pada masyarakat bugis termasuk Sidrap dan ini sangat mempengaruhi aspek budaya baik seni maupun aspek budaya lain. Konsep perahu secara implisit tidak hanya terbatas pada perahu secara tekstual namun memiliki makna filosofis yang begitu kompleks dalam kehidupan masyarakat bugis termasuk masyarakat bugis di kabupaten Sidrap dan inilah yang menyebabkan kacaping memiliki kemiripan dengan bentuk perahu. Generasi muda harus sadar bahwa mereka berasal dari nenek moyang yang hidup sebagai masyarakat perahu, artinya karakter pantang menyerah, bekerja keras harus melekat dalam diri mereka. Karakter tersebut terdapat dalam nilai masyarakat bugis yang dinamakan getting dan reso. Getteng adalah keteguhan hati yang jika dijabarkan dalam pendidikan karakter pada lingkungan formal meliputi nilai mandiri, disiplin, dan bertanggung jawab. Getteng juga merupakan bukti akan rasa cinta kepada tanah kelahiran (tanah air). Pelaut bugis sejak dulu memiliki semboyang pantang mundur surut ke pantai yang berarti tidak akan kembali sebelum mencapai kesuksesan adalah pencerminan nilai siri' pada masyarakat suku bugis Sidrap. Siri' adalah harga diri atau rasa malu yang dimiliki oleh masyarakat suku bugis yang harus tetap dipertahankan dan menjadi pendorong keberhasilan dalam menggapai cita-ci- 


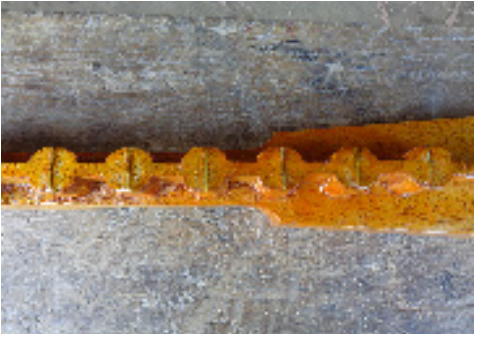

Gambar 3. Isi (Tuts ) kacaping

(Sumber: Dokumentasi Andi Ihsan)

ta.

Kacaping yang terlahir sebagai alat hiburan sejak awal menjadikan alat tersebut mudah berkembang, apalagi lahir pada masyarakat yang dinamis, mudah menerima sesuatu yang baru menjadikan alat ini sebagai alat musik yang mudah masuk pada seluruh aspek-aspek kehidupan karena masyarakat membutuhkannya sebagai media hiburan. Hal ersebut membuktikan bahwa masyarakat suku bugis Sidrap mudah berinteraksi dengan masyarakat lainnya serta dinamis artinya bisa masuk dimana saja. Hal ini dibuktikan dengan kebiasaan masyarakat suku bugis merantau sampai ke negeri seberang hingga menetap dan berkeluarga di wilayah manapun. Dalam nilai masyarakat bugis dinamakan Ammaccang yakni memiliki rasa ingin tahu yang tinggi dan selalu berusaha untuk mendapatkannya (reso). Nilai tersebut diharapkan dapat diwariskan kepada generasi saat ini melalui nilai estetika kacaping. Karakteristik suaranya yang riang sangat cocok didengar oleh masyarakat Sidrap yang memang pada dasarnya adalah masyarakat yang dinamis, begitupun dengan pola-pola petikannya yang cepat menjadikan masyarakat menggunakannya sebagai alat untuk menghibur baik secara individual maupun masyarakat secara kompleks. Tidak heran jika nada-nada yang dimainkan pada tuts kacaping bergerak secara dinamis dan penuh dengan improvisasi. Ini merupakan nilai yang melekat pada estetika kacaping dalam wujud perahu tersebut.

Perahu sebagai sumber kehidupan bagi masyarakat perairan menjadi alat untuk mencari ikan dan sebagai alat transportasi untuk melakukan aktifitas mencari nafkah pada wilayah-wilayah perairan di kabupaten Sidrap. Pada umumnya perahu yang digunakan oleh masyarakat dilakukan oleh laki-laki baik secara sendiri-sendiri maupun secara berkelompok. Biasanya jika mereka berkelompok, mereka membagi tugas masing-masing sesuai dengan keahliannya.

\section{Struktur Kacaping Bugis}

Secara Intrinsik, struktur kacaping bugis secara umum terdiri dari 3 (tiga) bagian besar dimana antara bagian yang satu dengan yang lainnya saling terkait. Bagian tersebut meliputi 1) Kepala, 2) Badan, dan 3) Ekor. Pada bagian kepala terdiri dari Lanjong yaitu bagian kepala tepatnya

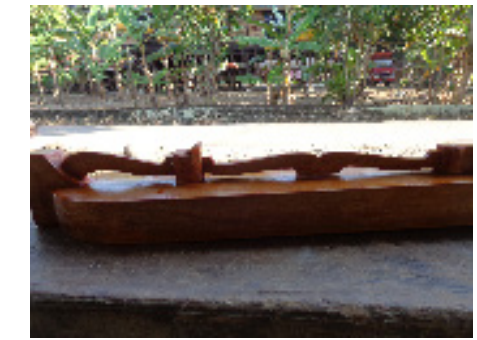

Gambar 4. Posi' (pengait senar) kacaping (Sumber: Dokumentasi Andi Ihsan)

bagian ujung dari kacaping, biasanya tipis dan kadang tebal tergantung dari bentuknya. Bagian ini menyerupai bentuk bagian depan dari perahu suku bugis di kabupaten Sidrap.

Bagian ini biasanya digunakan untuk tempat melekatkan doccili. Selanjutnya doccili yaitu bagian yang digunakan untuk menyetem senar terdiri dari 2 (dua) alat pemutar senar sesuai dengan jumlah senar dari kacaping. Bagian inilah yang menentukan ketepatan nada dari kacaping sebelum dimainkan.

Badan kacaping terdiri dari tuts, yaitu bagian yang digunakan untuk memainkan nada-nada dari kacaping, dalam bahasa bugis dinamakan Isi, dan Babua yang terletak pada bagian belakang kacaping, biasanya terdiri dari tiga 3 (tiga) lubang yang berfungsi untuk memperbesar bunyi dari kacaping. Makin besar lubang yang dibuat maka semakin besar pula bunyi yang dihasilkan.

Bagian ekor kacaping terdiri dari posi' yang berfungsi untuk mengait senar atau tali kacaping sehingga bisa terbentang, dan poncing yaitu bagian bawah kacaping, agak pendek dari bagian-bagian lainnya, ukurannya tergantung dari modelnya, ada yang tipis adapula yang tebal.

Secara ekstrinsik Struktur kacaping yang terdiri dari tiga (3) bagian tersebut memiliki persamaan dengan stratifikasi masyarakat Bugis dimana di dalam masyarakat bugis struktur dibagi ke dalam tiga yakni 1) Arung, 2) To Maradeka, 3) Ata. Ketiga struktur tersebut memiliki fungsi dan tingkatan yang berbeda dalam masyarakat bugis. Arung dalam masyarakat bugis adalah golongan status masyarakat yang biasa diartikan raja atau pemimpin, selanjutnya golongan To Maradeka yaitu golongan masyarakat biasa serta golongan Ata adalah golongan budak. Meskipun golongan stratifikasi tersebut berbeda-beda namun hal tersebut merupakan satu kesatuan yang tidak dapat dipisahkan seperti halnya dengan kacaping dengan kesatuan struktur mulai dari kepala, badan, dan ekor. Hal tersebut menegaskan bahwa konsep dari struktur kacaping tersebut bukan semata-mata dibuat hanya sebagai sebuah alat musik yang berfungsi atau bernilai seni hiburan saja, akan tetapi struktur kacaping memiliki makna melalui simbol-simbol dari struktur yang ada. 
Konsep kacaping sarat akan nilai-nilai yang mengacu pada filosofi kehidupan masyarakat bugis. Hubungan antara konsep struktur kacaping dengan konsep struktur masyarakat bugis sejak dulu telah ada dan diikuti oleh seluruh lapisan masyarakatnya meskipun status social masyarakat pada masa lampau sangat terlihat perbedaannya, namun secara fungsional mereka mampu bekerja secara bersama-sama sehingga hubungan antara kelompok pada strata atas seperti arung dengan kelompok menengah (to maradeka) serta kelompok masyarakat bawah (Ata) mampu menjalankan fungsinya masing-masing tanpa ada pertgesekan yang signifikan.

Arung sebagai golongan tertinggi pada masyarakat bugis merupakan pemimpin yang mengarahkan seluruh kegiatan di dalam masyarakat, seperti halnya dengan kepala pada bagian kacaping yang memiliki doccili untuk menyetem senar agar bisa dimainkan dengan benar. Kepala dalam hal ini menjadi hal pokok untuk memulai semua aktifitas. Seluruh aktifitas yang akan dilaksanakan sebelumnya diatur atau diarahkan oleh pemimpin dalam masyarakat yang dinamakan raja, demikian halnya pada kacaping sebelum dimainkan tentunya di sistem dengan benar barulah kemudian kacaping dapat dimainkan.

To Maradeka sebagai golongan masyarakat pelaksana tugas dari pemimpin atau raja, mereka melaksanakan seluruh aktifits yang telah diatur atau diarahkan oleh raja dapat dianalogikan sebagai bagian tengah dari kacaping yang tentunya terdiri dari Isi dan babua yang tentunya merupakan bagian dari kacaping untuk memainkan nada-nada serta lubang resonansi agar bunyi kacaping dapat terdengar. Di dalam masyarakat tentunya berbagai aktifitas dilakukan untuk menunjang kehidupan sehingga masyarakat dapat hidup tentunya dengan sesuai dengan aturan yang telah diatur oleh pemimpin masyarakat tersebut.

Golongan Ata sebagai golongan terendah pada masyarakat suku bugis yaitu mereka yang membantu aktifitas Arung maupun To Maradeka. Golongan ini memang selalu berada di bawah namun sangatlah penting artinnya bagi raja maupun pelaksana tugas. Golongan tersebut dapat diibaratkan sebagai bagian ekor dari kacaping yaitu posi yang berfungsi untuk mengait senar sehingga dapat terbentang dan dibunyikan. Kacaping merupakan representasi kehidupan masyarakat bugis Sidrap yang memiliki pranata-pranata, aturan-aturan, norma-norma serta adat istiadat yang diatur sedemikian rupa sehingga menjadi sebuah masyarakat yang memiliki struktur yang saling terkait antara yang satu dengan yang lainnya. Ritzer melihat sebiah struktur bahwa setiap struktur dalam sistem sosial, juga berlaku fungsional terhadap lainnya. Sebaliknya kalau tidak fungsional maka struktur itu tidak aka ada atau hilang dengan sendirinya. Demikian halnya dengan struktur dalam masyarakat kesenian di kabupaten Sidrap, struktur tersebut saling bekerjasama, meskipun dengan status sosial yang berbeda, namun tugas dan fungsi antara kelompok masyarakat yang satu dengan yang lainnya saling terkait sehingga sistem social masyarakatnya tetap berjalan dengan baik.

Jika dituangkan dalam nilai pendidikan karakter khususnya pada pendidikan formal, maka nilai estetika tersebut terumuskan dalam nilai masyarakat bugis yang dinamakan getting. Adanya pembagian kerja yang jelas, menjadikan masyarakat bugis mampu membagi wilayah kerja berdasarkan stratifikasinya masing-masing. Mereka tidak melihat tingkat stratifikasi tersebut, namun lebih kepada tanggung jawab (getting) dari tugas yang diembannya. Demikian halnya dengan nilai Assitinajang, yakni sadar akan kedudukan atau posisi masing-masing. Hal tersebut membentuk rasa demokratis, menghargai prestasi antar sesama, bersahabat, serta cinta damai. Hal itu disebabkan karena mereka sadar akan persatuan yang dibentuk melalu kerjasama dan tanggung jawab dalam menjalankan tugas masing-masing. Inilah yang diharapkan teraplikasi melalui estetika kacaping tersebut di dalam proses pembelajaran formal di sekolah.

\section{Warna dan Bahan baku Kacaping}

Kacaping sebagai salah-satu produk budaya masyarakat suku bugis di kabupaten Sidrap memiliki warna yang alami yang memang menjadi warna dasar dari kayu. Warna kecoklatan adalah warna yang umum digunakan dan warna tersebut mengikuti warna rumah khas orang bugis di kabupaten Sidrap yang memang bahan bakunya berasal dari kayu. Warna natural secera ekstrinsik memberikan penggambaran bahwa hubungan antara manusia dan alam sangatlah penting, manusia harus melihat alam sebagai bagian dari dirinya. Tanpa alam, manusia tidak akan bisa berbuat apa-apa, sehingga wajib bagi nmanusia untuk menjaganya. Warna natural ini juga memberi gambaran bahwa sesuatu yang natural akan mampu bertahan lama dan akan diterima oleh segala sesuatu yang ada di ala mini, ketika manusia mampu mempertahankan dengan menjaganya, maka segala hal yang dilakukan oleh manusia akan bisa bertahan sampai akhir hayat.

Kayu sebagai bahan baku utama pada instrumen kecapi pada dasarnya banyak terdapat di kabupaten Sidrap. Lingkungan alam kabupaten Sidrap yang masih banyak terdapat hutan merupakan modal dasar mudahnya bahan baku kayu didapatkan oleh pembuat kacaping. Beberapa jenis kayu yang banyak digunakan sebagai bahan dasar kacaping masih bisa ditemukan di beberapa tempat yang ada di kabupaten Sidrap.

Jenis kayu nangka menjadi kayu yang paling umum untuk dijadikan bahan baku pembuatan kacaping di kabupaten Sidrap. Selain memang masih sangat banyak ditemukan di hampir semua wilayah, kualitas kayu nangka juga dianggap oleh sebagian besar pembuat kacaping maupun pakkacaping sebagai kayu yang menghasilkan kualitas bunyi yang baik. Adanya ketersediaan bahan baku kayu sehingga melahirkan kacaping merupakan proses deter- 


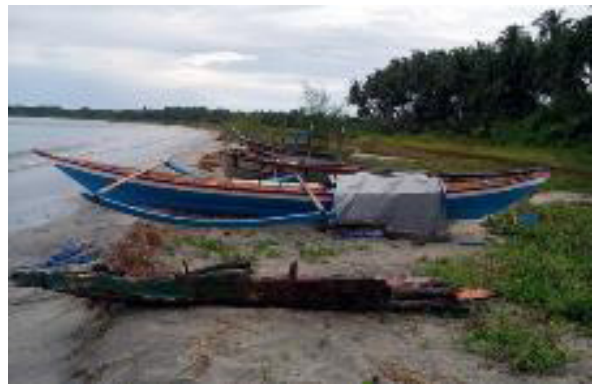

Gambar 5. Perahu Orang Bugis

(Sumber: Dokumentasi Andi Ihsan)

minasi lingkungan yang saling mendukung antara alam dan budaya yang dihasilkan. Julian H Steward menyebut determinasi sebagai kebudayaan suatu masyarakat yang terbentuk sebaga akibat dari kondisi lingkungan alam fisik atau alam. Di sisi lain kayu merupakan bagian yang tidak bisa terpisahkan dalam seluruh aspek kehidupan orang bugis sehingga mereka selalu menjaga alam lingkungannya karena merasa bagian dari kehidupan mereka.

Kayu pada masyarakat bugis masih merupakan kebutuhan yang sangat penting dalam kehidupannya sehari hari. Sejak dulu masyarakat sudah menggunakan kayu sebagai bahan untuk membuat perahu yang digunakan oleh masyarakat yang erada di sekitar pesisir danau untuk mencari ikan etaupun sebagai alat transportasi air. Kayu kayu tersebut tentunya bukanlah kayu yang asal saja melainkan kayu yang secara kualitas merupakan kayu yang kuat, tahan air dan cocok digunakan di atas air.

Rumah-rumah orang bugis sampai saat ini masih banyak yang dibuat seperti rumah mereka dahulu yakni rumah kayu dimana hampir semua bahan bakunya terbuat dari kayu. Bahkan menurut bapak Musafir sebagai salah-seorang warga di desa Amparita kabupaten Sidrap mengatakan bahwa rumah orang bugis Sidrap dulu semuanya terbuat dari bahan kayu kecuali atapnya. Jenis kayu yang digunakannyapun biasanya tergantung dari kemampuan sipemilik rumah, jadi untuk jenis kayunya biasanya bervariasi, ada yang menggunakan kayu yang berkualitas baik, dan ada pula yang menggunakan kayu biasa (Wawancara pada 11 Desember 2017 di desa Amparita),

Selain kayu dibuat sebagai rumah tempat tinggal, masyarakat bugis Sidrap juga menggunakan kayu sebagai bahan bakar untuk memasak. Penggunaan kayu sebagai bahan bakar untuk memasak tidak berarti karena tidak ada alat memasak yang modern seperti kompor, namun kayu digunakan untuk memasak memang memberikan hasil yang berbeda ketika menggunakan alat memasak lainnya. Kekhasan aroma itulah yang membuat masih banyak masyarakat yang menggunakannya sebagai bahan bakar meskipun warga tersebut termasuk warga yang memiliki tingkat ekonomi yang lebih bagus. Biasanya kayu-kayu untuk mereka gunakan sebagai bahan bakar di simpan di bawah rumah atau di sekitar halam rumah yang disusun

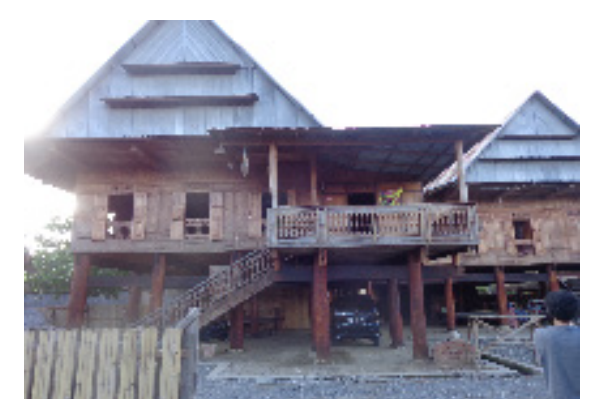

Gambar 6. Salah-satu rumah bugis di kabupaten Sidrap (Sumber: Dokumentasi Andi Ihsan)

atau diikat menjadi beberapa bagian dan diberi atap agar tidak terkena air ketika hujan datang.

Jenis kayu yang digunakan untuk pembuatan kacaping bermacam-macam, ada kayu nangka, kayu waru, kayu pinus, kayu agatis, bahkan ada yang dinamakan kayu katapi dan kayu cina-cina. Semua jenis kayu tersebut memiliki kelemahan dan kelebihan masing-masing. Namun diantara semua jenis kayu tersebut, jenis kayu nangka adalah kayu yang paling banyak digunakan sebagai bahan dasar membuat kacaping di kabupaten Sidrap ini. Selain masih mudah didapatkan, menurut beberapa pemain kacaping, jenis kayu nangka memiliki suara yang bagus bila dijadikan bahan alat music kacaping. Menurut bapak Damis Kattang, pembuat kacaping yang ada di Pangkajene kabupaten Sidrap bahwa kayu nangka sangat bagus dibuat kacaping karena hamper semua buatan beliau dibuat dengan menggunakan kayu nangka. Suaranya yang tebal dan lebar membuat pak Damis selalu membuat kacaping dengan bahan baku kayu jenis kayu nangka ini. Biasanya kayu tersebut dibuat dalam bentuk kotak-kotak yang telah diukur panjang dan lebarnya untuk menjadi satu buah kacaping.

Alam sebagai sumber utama kehidupan masyarakat bugis di Sidrap telah dilakukan sejak dahulu dan sebahagian besar masih berlangsung pada saat ini khususnya pada masyarakat yang konservatif dan masih memegang teguh adat dalam kehidupannya sehari-hari. Pada masyarakat bugis adat, mulai disemaikan dari masa kanak-kanak. Ada pesan yang mengungkapkan "Mari kita membuat pagar di bawah rumah kita, Ayo kita menanam adat, menyemarakkan kembang melati, subur kiranya adat kita, semarak kembang melati kita (Tappallla-palla ripassirinna bolata', tataneng ade', tappallimpo bunga pute, sawe ade 'ta, mallimpo bunga puteta). Dari nyanyian ini diketahui bahwa sebelum adat ditanamkan, pagarnya dahulu yang harus disiapkan. Dalam sejarah mencatat bahwa ada 2 yang dijadikan pagar yaitu bunga nangka dan hiasan kuku. Oleh orang bugis bunga nangka disebut lempu yang berarti lurus atau jujur, dan hiasan kuku adalah pacci yang berarti bersih atau suci. Ungkapan di atas bermakna adat dapat berjalan dengan baik jika dibarengi dengan kejujuran dan hati yang bersih. Hal inilah yang harus terus menerus diwariskan pada generasi muda atau pelanjut melalui organologi kecapi yang bahan utamanya menggunakan pohon lempu (nangka) 


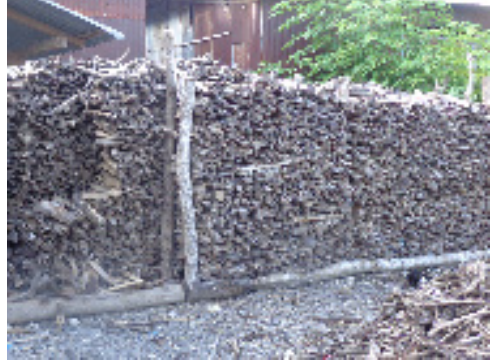

Gambar 7. Kayu yang digunakan untuk bahan bakar memasak di kabupaten Sidrap (Sumber: Dokumentasi Andi Ihsan)

tadi.

Kayu nangka dalam bahasa bugis disebut lempu'. Secara falsafah orang bugis dapat diartikan lurus yang memiliki makna kejujuran. Menurut Rahman Rahim (2011:119) leтрu' sama dengan lurus sebagai lawan dari bengkok. Dalam berbagai konteks, adakalanya kata ini berarti juga ikhlas, benar, baik atau adil sehingga kata-kata lawannya adalah culas, curang, dusta, khianat, seleweng, buruk, tipu, curang dan semacamnya. Arti-arti ini dapat dipahami ketika ditemukan kata lempu' dalam ungkapan bugis atau lontara'.

Pengertian ini memberi makna bahwa kacaping dalam pemilihan bahannyapun sarat dengan nilai-nilai filosofi masyarakat bugis. Kacaping tidak hanya sekedar dibuat begitu saja, namun dalam proses pembuatannyapun dimulai dari bahan yang digunakan sudah mengandung nilai-nilai yang seharusnya dipahami oleh generasi muda sebagai nilai yang harus dipedomani dan diamalkan dalam kehidupan sehari-hari. Nilai kejujuran melekat pada material pembuatan kacaping yaitu kayu nangka yang seharusnya bisa diajarkan kepada generasi muda, bukan hanya pada aspek teknik memainkannya saja. Di dalam nilai karakter pada pendidikan saat ini lempu' dapat kita sepadankan dengan kejujuran. Hal ini merupakan karakter yang harus tertanam dalam diri setiap generasi masyarakat suku bugis, dan tentunya dapat dijabarkan melalui estetika kacaping pada ruang pendidikan formal di sekolah- sekolah.

\section{SIMPULAN}

Dari uraian di atas, jelas terlihat bagaimana estetika kacaping memiliki nilai-nilai yang sangat erat hubungannya dengan nilai pendidikan karakter yang telah dicanangkan oleh pemerintah saat ini. Kacaping merupakan representasi dari masyarakat bugis dikabupaten Sidrap yang bila kita urai secara detail akan menghasilkan nilai-nilai kebudayaan masyarakat bugis, dan nilai tersebut dapat disadur dan dimasukkan dalam konsep pendidikan karakter dalam pendidikan formal yang selama ini dalam proses pembelajarannya terkesan hanya menekankan pada aspek keterampilan saja. Melalui nilai estetika kacaping tersebut, maka dapat dikombinasikan antara ke 18 nilai karakter yang ada dengan nilai-nilai kebudayaan masyarakat bugis. Adapun konsep tersebut, dapat kita lihat melalui matriks di bawah ini:

\begin{tabular}{|c|c|c|}
\hline Kacaping & $\begin{array}{l}\text { Nilai kebudayaan } \\
\text { Bugis }\end{array}$ & $\begin{array}{l}\text { Nilai Pendidikan } \\
\text { Karakter }\end{array}$ \\
\hline Bentuk Perahu & $\begin{array}{l}\text { Ammaccang, Reso, } \\
\text { Siri, getteng }\end{array}$ & $\begin{array}{l}\text { Kerja keras, Cinta } \\
\text { Tanah Air,Di- } \\
\text { siplin, Tanggung } \\
\text { Jawab, Mandiri, } \\
\text { Gemar membaca, } \\
\text { Kreatif, Rasa Ingin } \\
\text { Tahu, Semangat } \\
\text { kebangsaan }\end{array}$ \\
\hline
\end{tabular}

\begin{tabular}{|c|c|c|}
\hline Struktur & Getteng, Assitinajang & Demokratis, \\
\hline $\begin{array}{l}\text { Kepala (Lan- } \\
\text { jong) }\end{array}$ & & $\begin{array}{l}\text { Menghargai } \\
\text { Prestasi, Bersa } \\
\text { bat, Cinta Dam }\end{array}$ \\
\hline Badan (Isi) & & la \\
\hline Ekor (Posi) & & \\
\hline $\begin{array}{l}\text { Warna dan Bah- } \\
\text { an Baku }\end{array}$ & & $\begin{array}{l}\text { Jujur, Peduli } \\
\text { Lingkungan, }\end{array}$ \\
\hline $\begin{array}{l}\text { Coklat, kayu } \\
\text { Nangka }\end{array}$ & Lempu, Getteng & \\
\hline
\end{tabular}

Selanjutnya bisa di tuangkan dalam pembelajaran sehingga siswa tidak hanya mengenal kacaping dari aspek pengetahuan dan psikomotornya saja, namun melalui kacaping tersebut, dapat ditanamkan sikap-sikap kepada siswa apa yang ada pada nilai kebudayaan bugis tersebut. Dengan demikian jika ini dilakukan terus menerus maka tujuan yang ingin dicapai melalui pembelajaran kacaping tersebut benar-benar akan dapat dimaksimalkan khususnya bagaimana membangun karakter siswa khususnya karakter yang sesuai dengan budaya daerahnya masing-masing.

\section{DAFTAR RUJUKAN}

Ganap, Victor. (2012). Konsep Multikulturaldan Etnisitas Pribumi dalam Penelitian seni. Jurnal Humaniora. 24(2): 156-167.

Gie, The Liang. (1976), Garis Besar Estetik (Falsafah Keindahan). (Cetakan ke-2). Yogyakarta: Fakultas Filsafat Universitas Gajah Mada.

Hasan, Salahuddin. (1995), Kecapi Bugis Makassar: Bagian Proyek Pembinaan Permuseuman Sulawesi Selatan.

Kluckhohn, C. dan Strodtbeck. (1961). Variatioan in Values Orientation. Englewood Cliffs, N.J.: Prentice-Hall.) 
Mattulada. (1975). “Latoa satu lukisan analitik terhadap antropologi-politik Orang Bugis". Universitas Indonesia, Jakarta.

Merriam, Alan P. (1999). The Anthropology of Music.Terjemahan Triyono Bramantyo. Yogyakarta: ISI Yogyakarta.

Miles, Matthew. B. Miles dan A. Michael Huberman. (2007). Analisis Data Kualitatif Buku Sumber Tentang Metode-metode Baru. Terjemahan Tjetjep Rohendi Rohidi. Jakarta: Universitas Indonesia.

Moleong, Lexy J. (2006). Metode Penelitian Kualitatif. Bandung: Rosdakarya.

Rahim, A. Rahman. (2011). Nilai-nilai Utama Kebudayaan Bugis: Penerbit Ombak: Yogyakarta.

Sugiyono. (2006). Metode Penelitian Pendidikan (Pendekatan Kuantitatif, Kualitatif dan R\&D). Bandung: Alfabeta.

Taylor, Edward. B. (1958). Primitive Culture. Harper, New York.

Tjetjep, R. (2011). Metodologi Penelitian Seni. Semarang: Cipta Prima Nusantara. 